\title{
A vegetation survey of the Tsitsikamma Coastal National Park
}

\author{
N. HANEKOM, A. SOUTHWOOD and M. FERGUSON
}

Hanekom, N., A. Southwood and M. Ferguson. 1989. A vegetation survey of the Tsitsikamma Coastal National Park. - Koedoe 32 (1): 47-66. Pretoria. ISSN $0075-6458$.

\begin{abstract}
Sampling plots ( $5 \mathrm{~m} \times 10 \mathrm{~m}$ in fynbos, $10 \mathrm{~m} \times 10 \mathrm{~m}$ in forest) were analysed in the littoral, coastal escarpment, and north and south facing inland escarpment zones of 17 transect sites along the Tength of the Tsitsikamma Coastal National Park. Cover-abundance values were estimated for each species in the sampling plots A detrended correspondence analysis (using CANOCO) and a two way indicator species analysis (TWINSPAN) were carried out on these data to determine the communities sampled. The vegetation of the park was classified into an Afromontane Forest, a Littoral Herbland and two Mesic Mountain Fynbos Communities. The distribution and extent of these communities were determined and their conservation discussed.
\end{abstract}

Key words: Tsitsikamma Coastal National Park, vegetation survey, Mesic Mountain Fynbos, Afromontane Forest.

N. Hanekom, Tsissikamma Coastal National Park, P.O. Storms River, 6308 Republic of South Africa, A. Southwood, Department of Nature and Environment Conservation C.P,A., Private Bag X6546, George, 6530 Republic of South Africa, M. Ferguson, Department of Environmental Affairs, Forestry Branch Tsitsikamma Region, Private Bag X537, Humansdorp, 6300 Republic of South Africa.

\section{Introduction}

The more common trees and flowering plants of the Tsitsikamma Coastal National Park (TCNP) have been described by Courtney-Latimer, Smith, Bokelmann \& Batten (1967) and Rycroft (1980), but except for work by Pretorius, Bond, Odendaal, Geldenhuys \& Breytenbach (1980), the detailed composition of the various plant communities within the park has been ignored. The aim of this project was to identify, describe and map these communities. Such work would provide basic data for management prescriptions, as well as giving an indication of the potential importance of the TCNP in the conservation of certain vegetation types. The work complements studies done in other nature reserves of the southern and eastern Cape (Grobler \& Marais 1967; Taylor 1970a, 1970b; Penzhorn \& Olivier 1974; Van der Merwe, 1976, 1977).

The TCNP is situated in the southern Cape (Fig. 1), In the De Vasselot area (Fig. 2a), the park extends 3 to $4 \mathrm{~km}$ inland along the escarpments 
( $c a 40 \mathrm{~m}-220 \mathrm{~m}$ above sea level) of the Brak, Sout, Bobbejaans and Groot rivers, while to the east of Nature's Valley (Figs. 2b, 2c) it is restricted mainly to the steeply sloping coastal escarpment ( $c a 80 \mathrm{~m}-$ $120 \mathrm{~m}$ high). The major geological formations underlying the park are of the Table Mountain Group (Kleinrivier Formation of Toerien (1976) incorrect) and the Bokkeveld Group (occuring in a broad band in the Sout River and Brak River areas). Soils are primarily lithosolic or colluvial, varying from shallow to moderately deep. The climate is mild (mean monthly temperatures ranging from about $12^{\circ} \mathrm{C}$ to $20^{\circ} \mathrm{C}$ ), with an annual rainfall of approximately $1140 \mathrm{~mm}$ more or less evenly distributed throughout the year (Fig. 3).

\section{Methods}

The landward boundaries of the TCNP were determined from descriptions and measurements listed in the Government Gazette of June 1974, Statutes of the Republic of South Africa (1976) and internal reports of the National Parks Board. These boundaries were plotted on 1:10 000 orthophotographs. The latter and private 1:4000 aerial colour prints were used to determine the distribution of the various vegetation types.

Inspection of the forest and fynbos patches, that occur along the length of the park, showed changes in the vegetation as one progressed northwards away from the sea and the communities of the small littoral plateau, the steep coastal escarpment, and the sheltered north and south facing inland escarpments appeared to differ from each other. Seventeen north-south transects were therefore done along the length of the park (Fig. 2) and each transect was partitioned into zones namely, littoral, coastal escarpment, and north and south facing inland escarpments. The littoral and inland escarpment zones are absent at Transects 1, 2, 3, 4, 6, 9 and 15 and 12 respectively, while the direction and extent of the transects done at Sites $2 \mathrm{c}$ and 4 were altered to exclude newly ( $<3$ years old) burnt areas. A sampling plot $(5 \mathrm{~m} \times$ $10 \mathrm{~m}$ in fynbos and $10 \mathrm{~m} \times 10 \mathrm{~m}$ in forest) was analysed in the lower, middle and upper sections of each transect zone, except in the narrow littoral zone, where only the middle section was sampled. The sizes of the sampling plots used corresponded to that employed by Taylor (1969), Bond (1981) and Campbell (1985) in fynbos $(5 \mathrm{~m} \times 10 \mathrm{~m})$ and that used by McKenzie (1978) in forest $(10 \mathrm{~m} \times 10 \mathrm{~m})$. The fynbos studied was assessed to be mature (older than 8 years), except for patches (covering about one third of the sampling area) on the inland escarpment zones of Sites $2 c, 6,11$ and 13 . These patches were about $3-6$ years old.

The structure of the vegetation was described according to Campbell, Cowling, Bond \& Kruger (1981), while the projected canopy cover-abundance of each species within the sampling plot was subjectively estimated on modified Braun-Blanquet scale (Werger 1974). The scale used is as follows:

$r=$ very rare and with negligible cover

$+=$ present, but not abundant and with a small cover value ( $<1$ percent)

$1=$ fairly numerous, but cover $<1$ percent, or not so numerous and cover $1-5$ percent

$2 \mathrm{a}=$ cover $6-12$ percent

$2 \mathrm{~b}=$ cover $13-25$ percent

$3=$ cover $26-50$ percent

$4=$ cover $51-75$ percent

$5=\operatorname{cover} 76-100$ percent

Sampling was concentrated on determining major groupings in the vegetation and rare species were probably overlooked. In the forest assessments, additional measurements of stem diameters at breast height (DBH) were made of larger trees (DBH $>10 \mathrm{~cm}$ ) and the foliage architecture of the canopy trees was assessed (Geldenhuys, Knight \& Jarman 


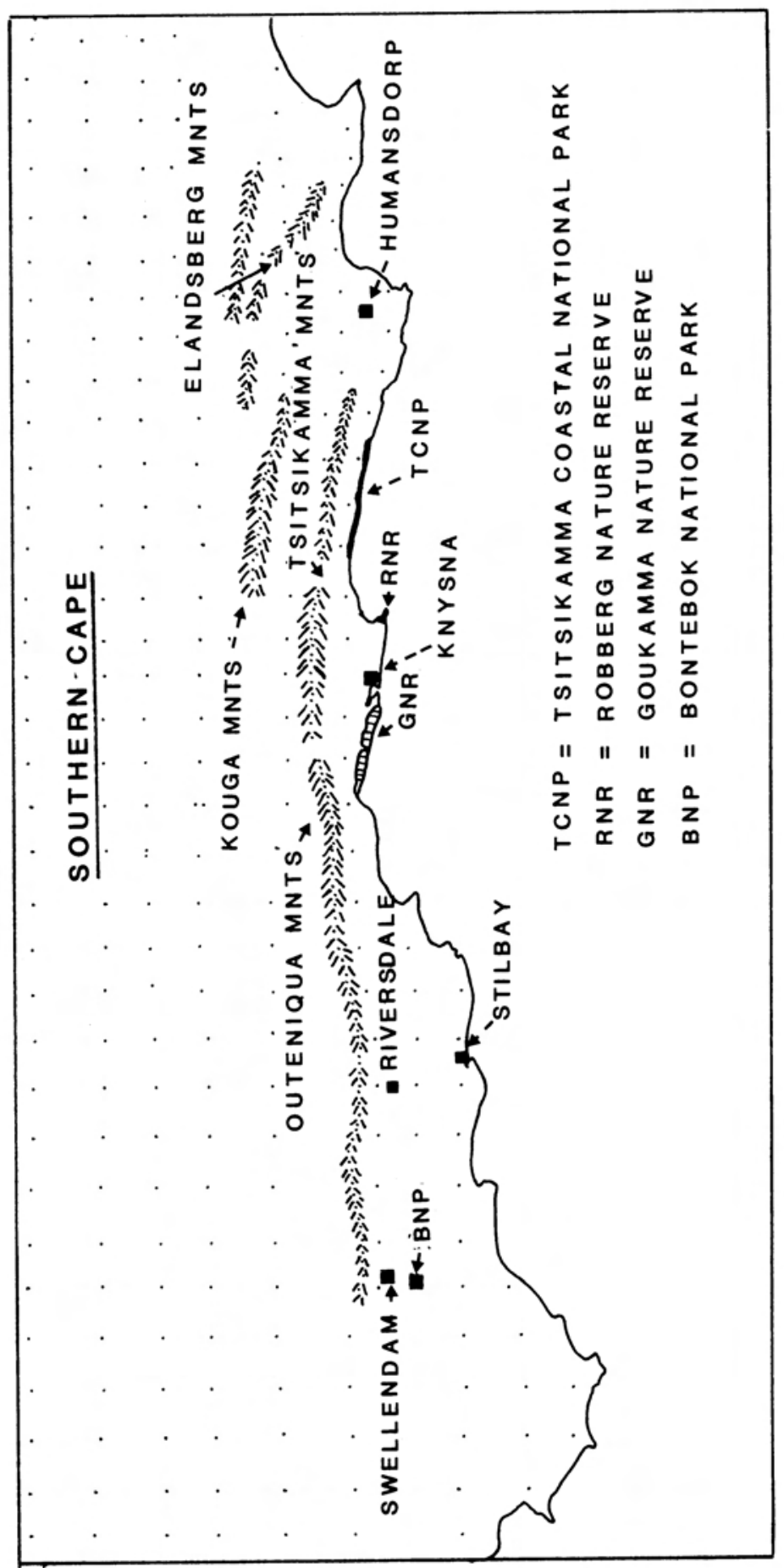

Fig. 1. Map of southern Cape showing the geographical position of the Tsitsikamma Coastal National Park and other sites mentioned in text. 

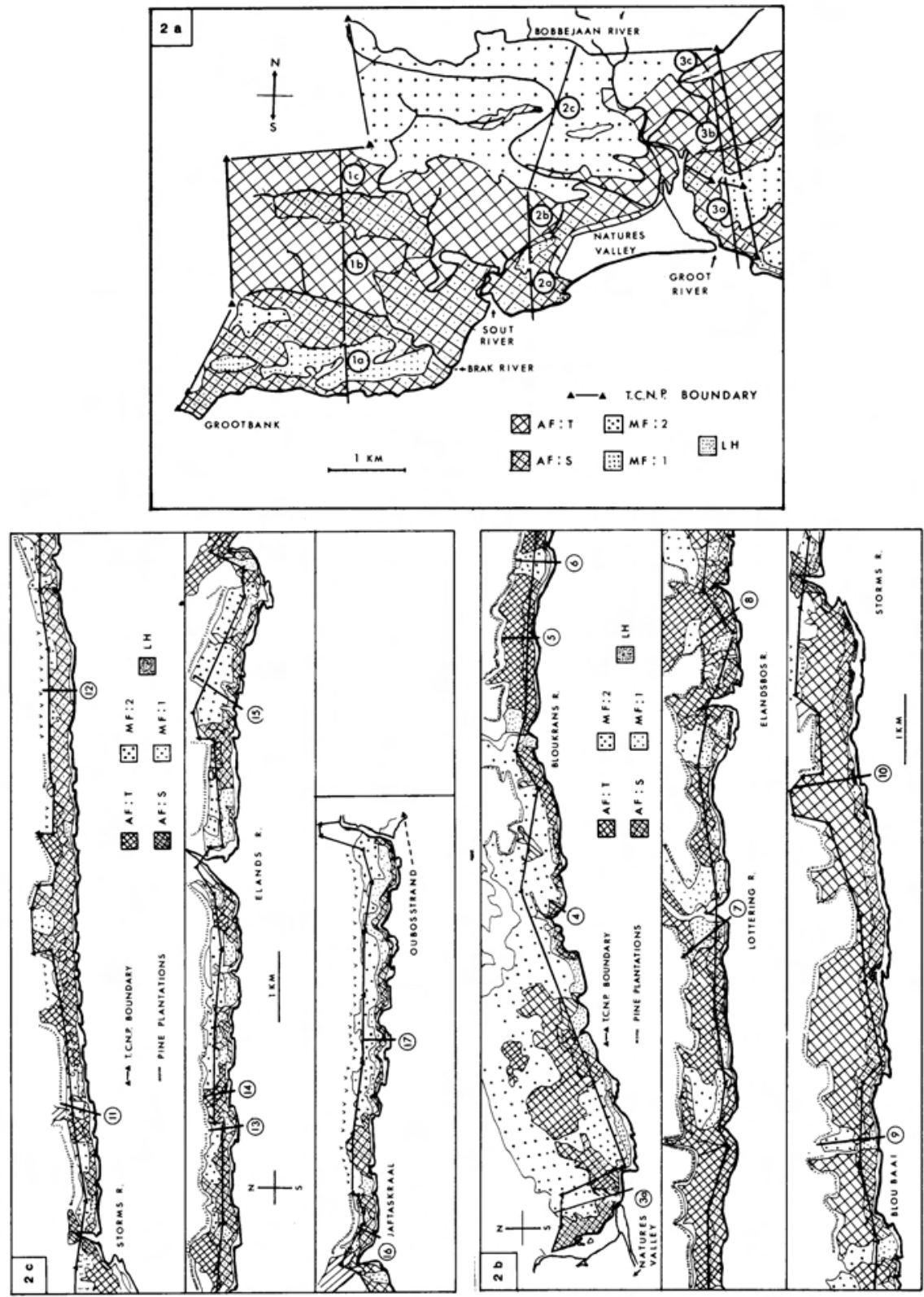

Fig. 2 a-c. Map of the Tsitsikamma Coastal National Park $(2 \mathrm{a}=$ De Vasselot section, $2 \mathrm{~b}$ and $2 \mathrm{c}=$ central and eastern sectors of the park respectively) showing transect sites and distribution of the various vegetation types.

Key: AF:T = Afromontane Forest (tall forests) of the south facing inland escarpments. AF:S = Afromontane Forest (stunted forest) of the coastal and north facing inland escarpments and the southern escarpments of Sites 1a and 2a. MF:1 Mesic Mountain Fynbos (community one (Panaea cneorum - Tetraria capillacea Fynbos)) found primarily on the inland escarpments. MF:2 Mesic Mountain Fynbos (community two)), found primarily on the coastal escarpment. LH: Littoral herbland restricted to the coastal Plateau. 


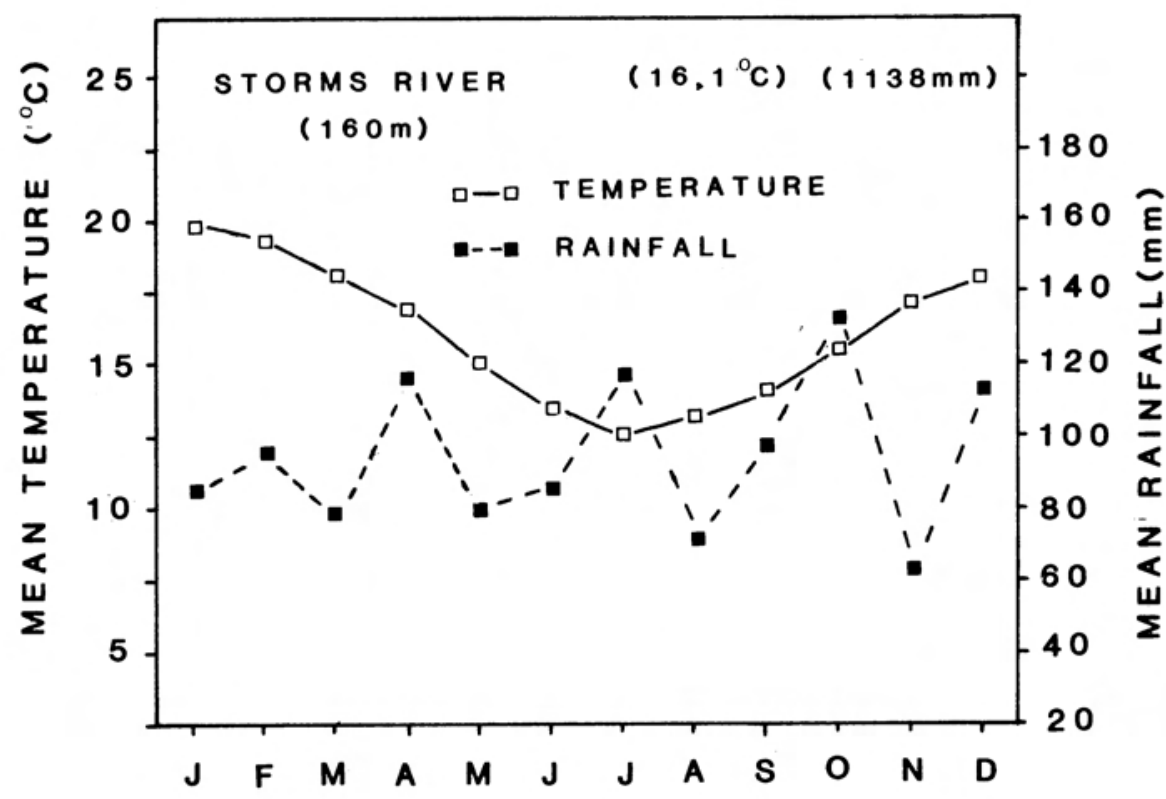

\section{MONTHS}

Fig. 3. Mean of monthly air temperature and rainfall values recorded in the Storms River region between 1982 - 1986, while the altitude of site and the mean annual air temperature and rainfall are listed above. (Data derived from Hanekom \& Bower 1988).

1987). Plant specimens were identified from herbaria samples or by personnel of the Saasveld Forestry Research Centre and Kirstenbosch Botanical Gardens Herbaria. Nomenclature follows Bond \& Goldblatt (1984).

The cover abundance values for the upper, middle and lower sections of each transect zone were pooled and mean values calculated. A detrended correspondence analysis (using CANOCO, Ter Braak 1987) and a two way indicator species analysis (TWINSPAN, Hill 1979) were carried out on these data (except those of Site $3 \mathrm{bN}$ (fynbos), which were inconsistent with the other data sets). The former analysis is an ordination technique based on reciprocal averaging (Hill 1973) and the end product is a two dimensional scatter diagram with similar samples (or sites) located together and dissimilar entities far apart (Ter Braak 1987). TWINSPAN produces a classification of stands by progressive splitting of ordinations (reciprocal averaging) at their centre of gravity. At each split indicator (diagnostic) species are chosen to define the two groups of data and serious misclassifications are rare (Hill 1979). This technique has been used successfully in fynbos and forest communities (Bond 1981; Cowling 1984). The plant communities identified were plotted on an 1:10 000 orthophotograph and the area (flat surface, contours ignored) occupied was determined using a planimeter.

\section{Results}

The "groupings" of transect zones (or releves) by CANOCO and TWINSPAN were similar and suggested that the vegetation sampled consisted of one forest, one herbland and two fynbos communities (Fig. 4). 


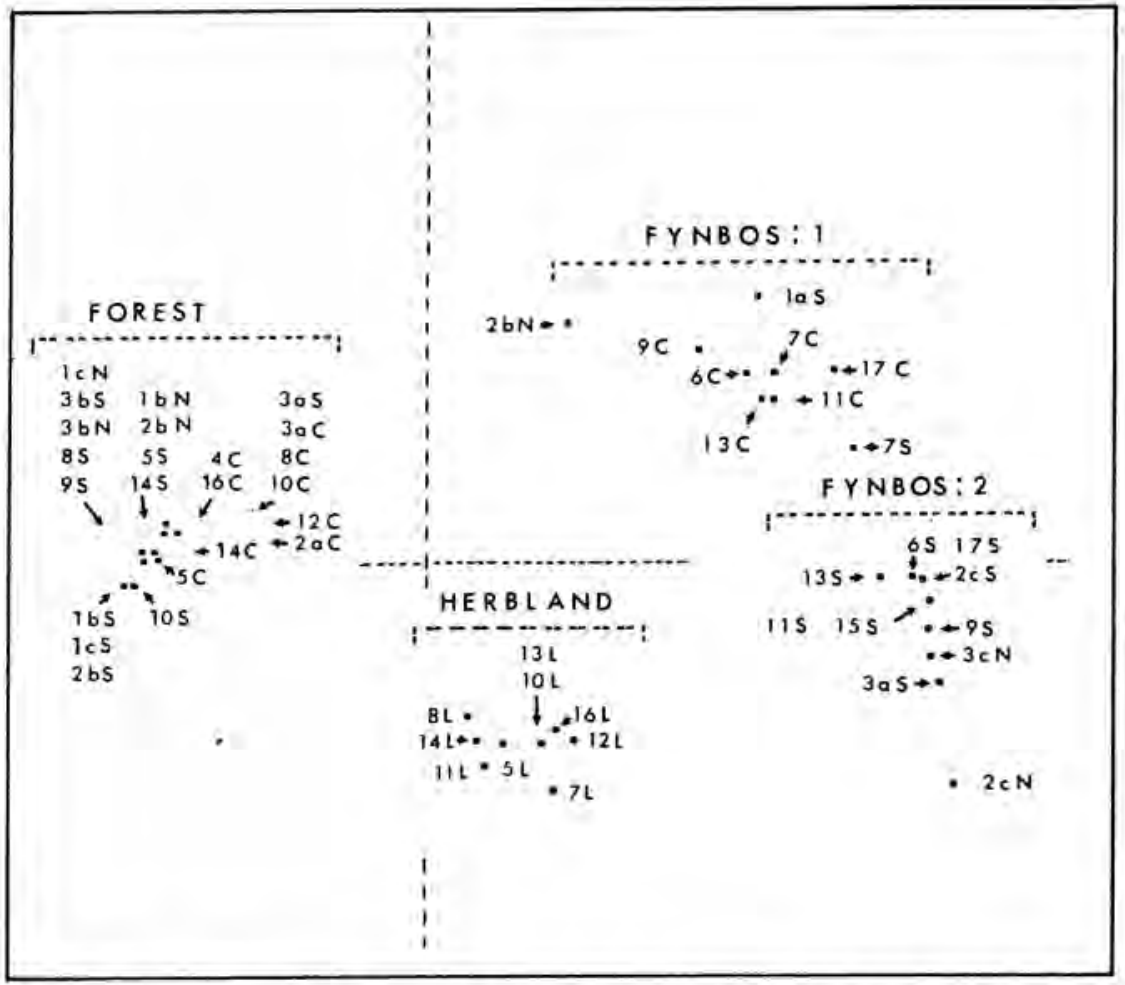

Fig. 4. Scatter diagram from a detrended correspondence analysis of CANOCO showing the grouping of the various sites into four communities (namely a forest, a littoral herbland and two fynbos groups).

The species composition of the forest community differs notably from the other releves studied (Fig. 4) and TWINSPAN listed 58 differential species, but no indicator (or diagnostic) species for this community (Table 1). The lack of indicator species is surprising, because many of the differential species are restricted to the forest sites (Tables 1-3). The community studied includes both the tall ( $c a 22 \mathrm{~m}$ ) multistoried forests of the sheltered south facing inland escarpments (Fig. 5a), as well as the stunted ( $c a 4 \mathrm{~m}-6 \mathrm{~m}$ high) forests of the drier coastal and north facing inland escarpments (Fig. 5b). The latter forests generally have thinner trees $($ mean DBH $(>10 \mathrm{~cm})=17 \mathrm{~cm} c f(22 \mathrm{~cm}))$ and a more diverse ground flora than the former group (Table 1). The strong clustering of the forest sites in Fig,4, however, gave no justification for further division of this forest community. Approximately 75 percent of the Afromontane tree species listed by White (1978) for the Knysna enclave were recorded in this community and it is, therefore, classed as Afromontane Forest. It covers about 2506 ha or 63 percent of the park (Fig. 2) and occurs (both as tall and stunted forests) in areas underlain by geological formations of the Bokkeveld and Table Mountain Groups. 


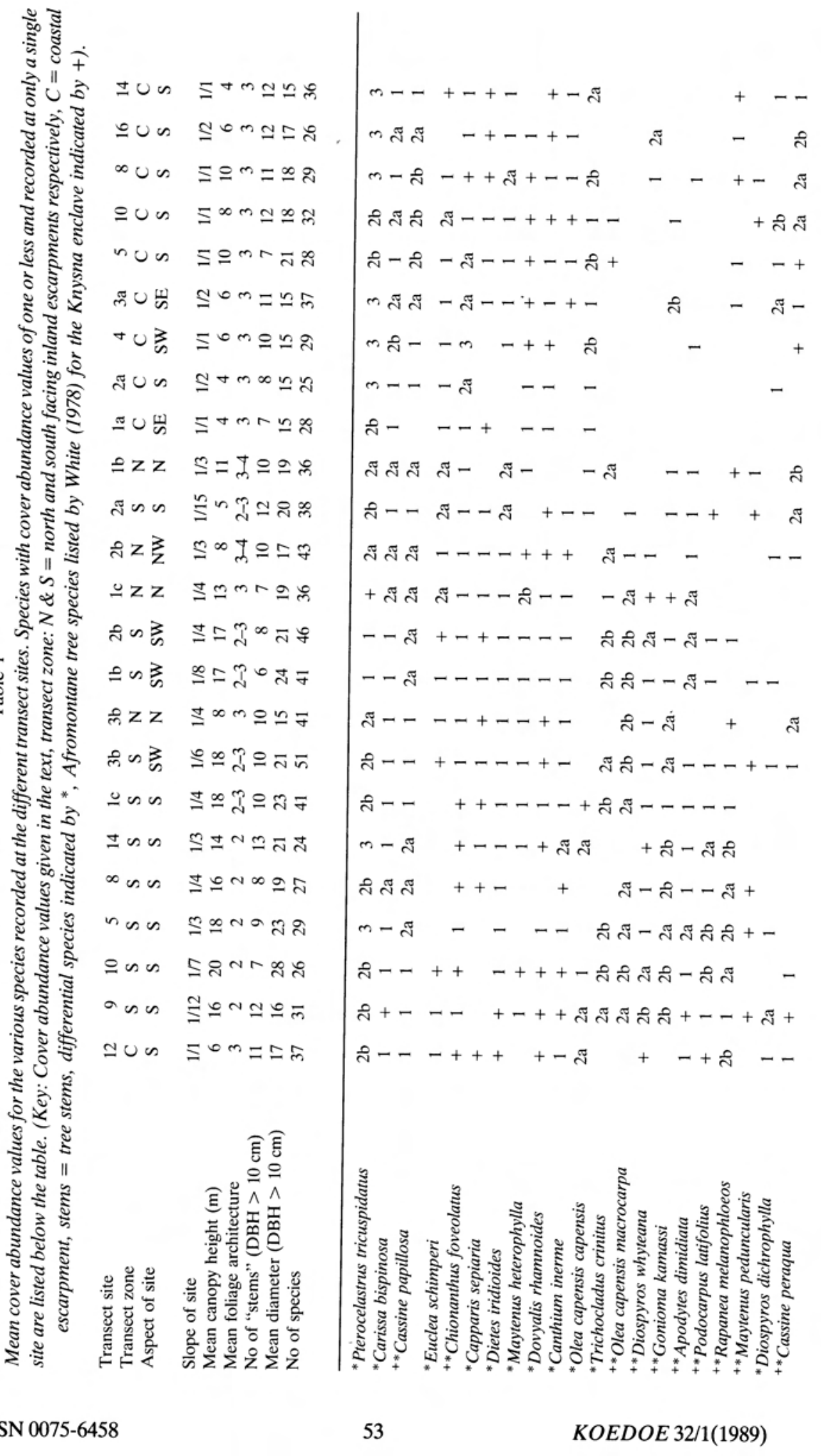




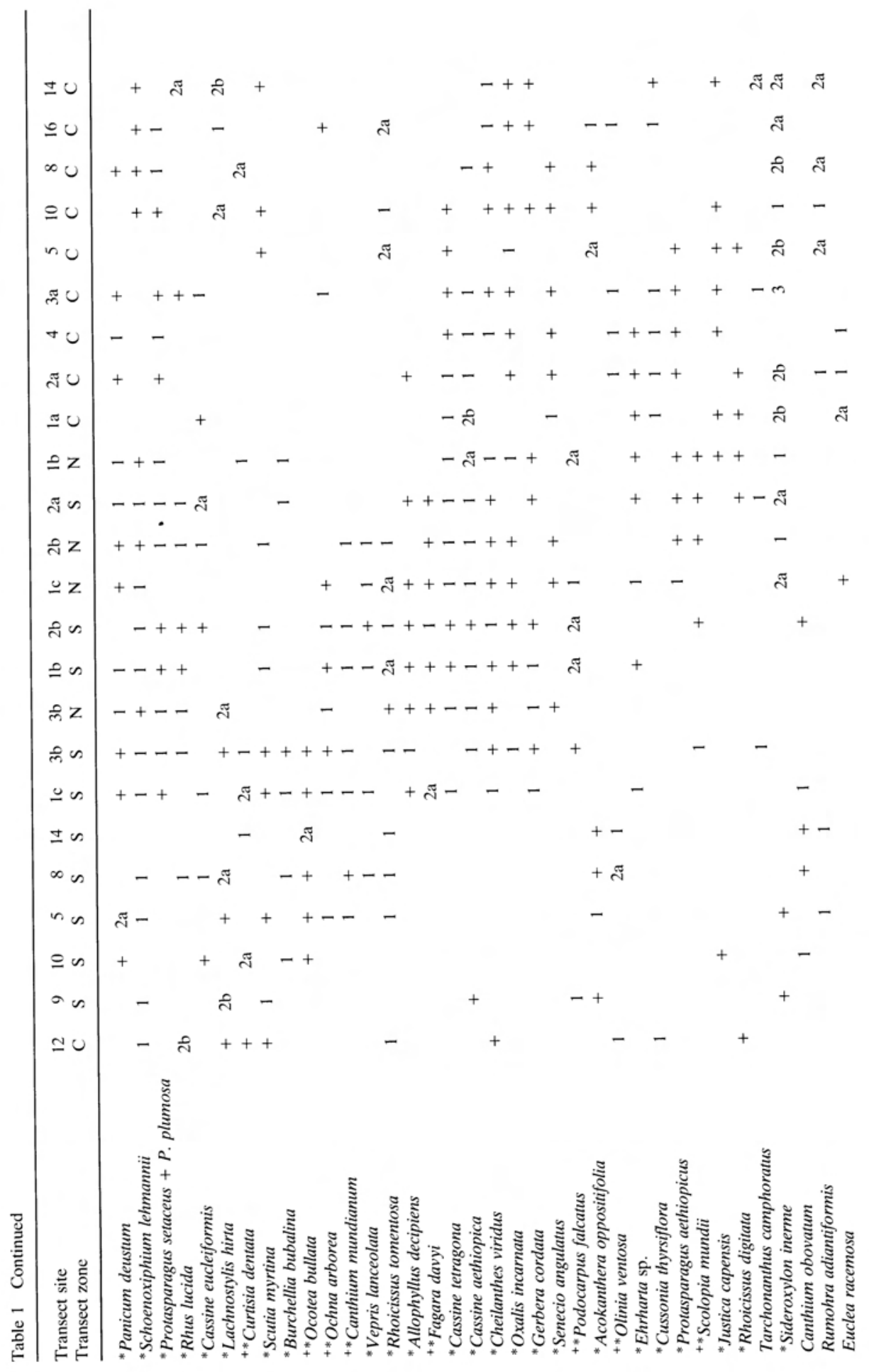




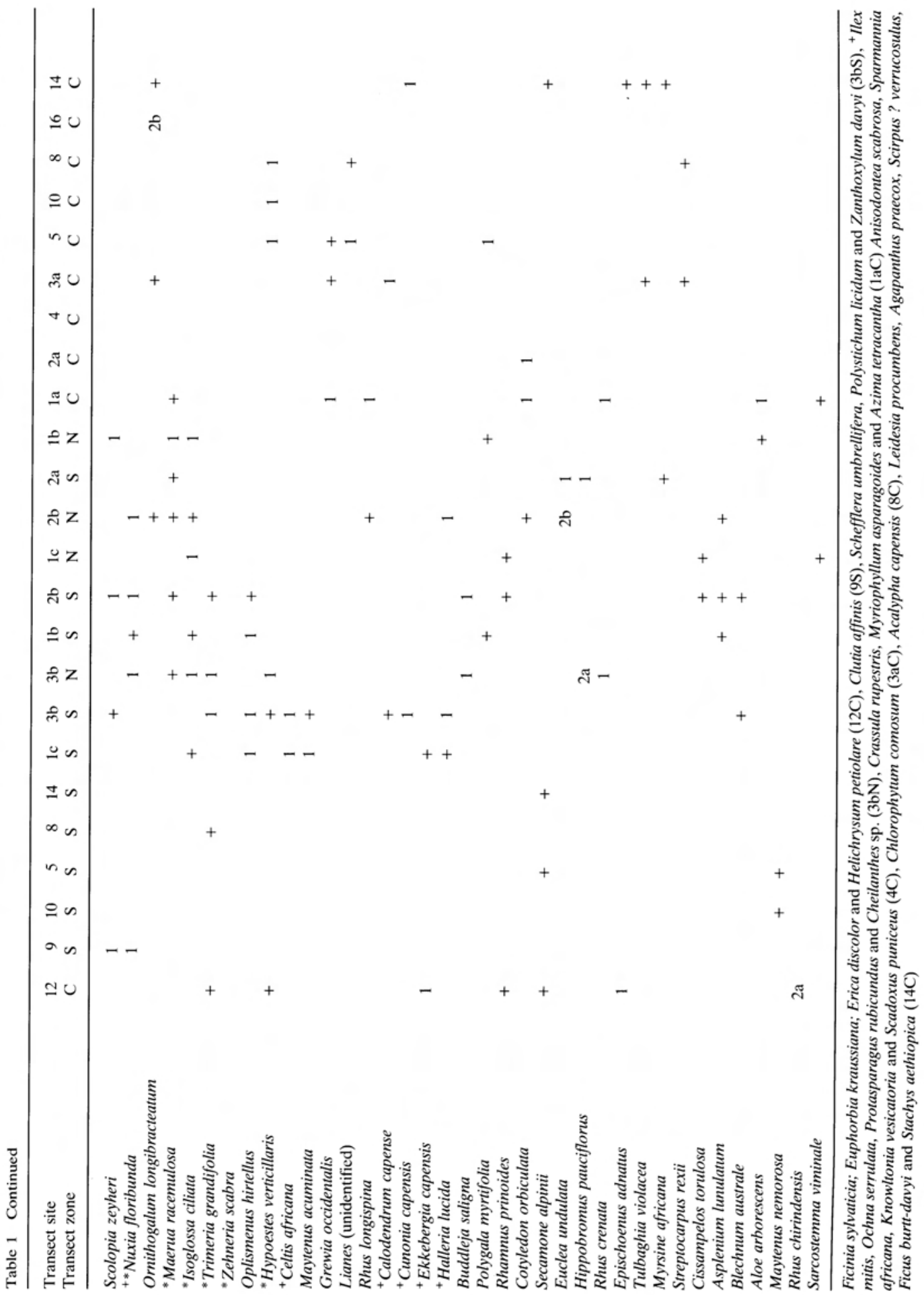


Table 2

Mean cover abundance values for the various species recorded at the different littoral herbland sites. Species with cover abundance values of one or less and recorded at a single site are listed below the table (Key: Cover abundance values given in text, vegetation types: $H=$ herbland; $S=$ shrubland; transect zone: $L=$ littoral; differential species indicated by asterisks)

Transect site

Transect zone

Aspect

Slope of site

Canopy cover (\%)

Vegetation types

Mean heigth (m)

No. species

$\begin{array}{llllllllll}5 & 8 & 16 & 7 & 11 & 13 & 10 & 12 & 17 & 14 \\ \mathrm{~L} & \mathrm{~L} & \mathrm{~L} & \mathrm{~L} & \mathrm{~L} & \mathrm{~L} & \mathrm{~L} & \mathrm{~L} & \mathrm{~L} & \mathrm{~L} \\ \mathrm{~S} & \mathrm{~S} & \mathrm{~S} & \mathrm{~S} & \mathrm{~S} & \mathrm{~S} & \mathrm{~S} & \mathrm{~S} & \mathrm{~S} & \mathrm{~S} \\ 1 / 3 & 1 / 6 & 1 / 4 & 1 / 4 & 1 / 3 & 1 / 3 & 1 / 6 & 1 / 4 & 1 / 6 & 1 / 2 \\ 100 & 75 & 60 & 80 & 80 & 80 & 100 & 95 & 75 & 75 \\ \mathrm{H} & \mathrm{H} / \mathrm{S} & \mathrm{H} & \mathrm{H} & \mathrm{H} & \mathrm{H} & \mathrm{H} & \mathrm{H} / \mathrm{S} & \mathrm{H} / \mathrm{S} & \mathrm{H} \\ 0,5 & 0,4 & 0,3 & 0,2 & 0,5 & 0,3 & 0,5 & 0,6 & 0,5 & 0,4 \\ 18 & 16 & 10 & 12 & 15 & 15 & 11 & 10 & 18 & 13\end{array}$

\begin{tabular}{|c|c|c|c|c|c|c|c|c|c|c|}
\hline \\
\hline \multicolumn{11}{|l|}{$\begin{array}{c}{ }^{*} \text { Carpobrotus } \\
\text { deliciosus } \\
{ }^{*} \text { Stenotaphrum }\end{array}$} \\
\hline secundatum & $2 \mathrm{~b}$ & 1 & & 1 & $2 \mathrm{~b}$ & 3 & $2 b$ & 1 & $2 \mathrm{a}$ & 3 \\
\hline $\begin{array}{l}{ }^{*} \text { Gazania linearis } \\
{ }^{*} \text { Helichrysum }\end{array}$ & & & $2 a$ & & $2 \mathrm{a}$ & 3 & \\
\hline dasyanthum & 3 & 3 & 1 & & & & 3 & $2 \mathrm{a}$ & $2 b$ & $2 b$ \\
\hline${ }^{*}$ Chironia baccifera & $2 \mathrm{a}$ & 1 & 1 & & & 1 & & & 1 & \\
\hline${ }^{*}$ Silene capensis & & + & $2 \mathrm{a}$ & & 1 & + & & & + & + \\
\hline${ }^{*}$ Polygala fruticosa & 1 & & & 1 & 1 & 1 & & 1 & 1 & 1 \\
\hline${ }^{*}$ Passerina vulgaris & & & & $2 b$ & & 1 & & $2 b$ & 1 & \\
\hline${ }^{*}$ Senecio angulatus & & & 1 & & 1 & 1 & & & & $2 b$ \\
\hline Sporobolus virginicus & & & & 1 & & 1 & & 1 & 1 & \\
\hline \multicolumn{11}{|l|}{${ }^{*}$ Cynodon dactylon $\}$} \\
\hline${ }^{*}$ Helichrysum teretifolium & & & & 1 & $2 \mathrm{a}$ & & & $2 \mathrm{~b}$ & + & \\
\hline${ }^{*}$ Maytenus procumbens & & & & & 1 & & 1 & & + & \\
\hline *Indigofera procumbens & + & + & 1 & 1 & + & & & & & \\
\hline${ }^{*}$ Hypoestes aristata & + & & 1 & & $2 \mathrm{a}$ & & & & 1 & \\
\hline${ }^{*}$ Rumohra adiantiformis & 1 & & & & 1 & & & & & $2 \mathrm{a}$ \\
\hline${ }^{*}$ Oxalis incarnata & + & 1 & 1 & & & & + & & & \\
\hline${ }^{*}$ Stachys aethiopica & & 1 & 3 & & & & & & & \\
\hline${ }^{*}$ Delosperma litorale & & & & 1 & & & & 1 & 1 & \\
\hline \multicolumn{11}{|l|}{$\begin{array}{c}{ }^{*} \text { Linum a fricanum } \\
\text { var. litorale }\end{array}$} \\
\hline${ }^{*}$ Samolus porosus & & + & & 1 & & + & & & & \\
\hline *Senecio purpureus & $2 a$ & & & & & & & & 1 & \\
\hline${ }^{*}$ Hippia frutenscens & & & & & & $2 a$ & & & & 1 \\
\hline Cassine tetragona & & $2 \mathrm{a}$ & & & + & & & & & \\
\hline $\begin{array}{l}{ }^{*} \text { Rhus crenata } \\
\text { Pterocelastrus }\end{array}$ & 1 & \\
\hline $\begin{array}{l}\text { Pterocelastrus } \\
\text { tricuspidatus }\end{array}$ & & & & & 1 & & & & & 1 \\
\hline${ }^{*}$ Scirpus nodosus & 1 & 1 & & & & & & & & \\
\hline${ }^{*}$ Thesidium spp. & & & & & & & & 1 & 1 & \\
\hline Rapanea melanophloeos & 1 & & & & & & + & & & \\
\hline Rhoicissus digitata & & & & & & & 1 & & + & \\
\hline $\begin{array}{l}\text { *Senecio elegans } \\
\text { Cullumia decurrens }\end{array}$ & 1 & & & & & $2 a$ & & & & + \\
\hline
\end{tabular}

Chrysanthemoides monilifera, Pelargonium capitatum and Sideroxylon inerme (5L), Jusitca capensis L tubulosa, Protasparagus aethiopicus and Osteospermum fruticosum (8L), Cotula turbinata (7L), Tarchonanthus camphoratus and Dipogon lignosus (11L), Dietes iridioides, Plantago crassifolia and Hypoxis? villosa (13L), Rumex sagittatus, Arctotheca calendula, Carex aethiopica and Otholobium sericeum (10L), Cussonia thyrsiflora and Cliffortia serpyllifolia (17L), Crassula cf rupestris and Erica discolor (14L). 


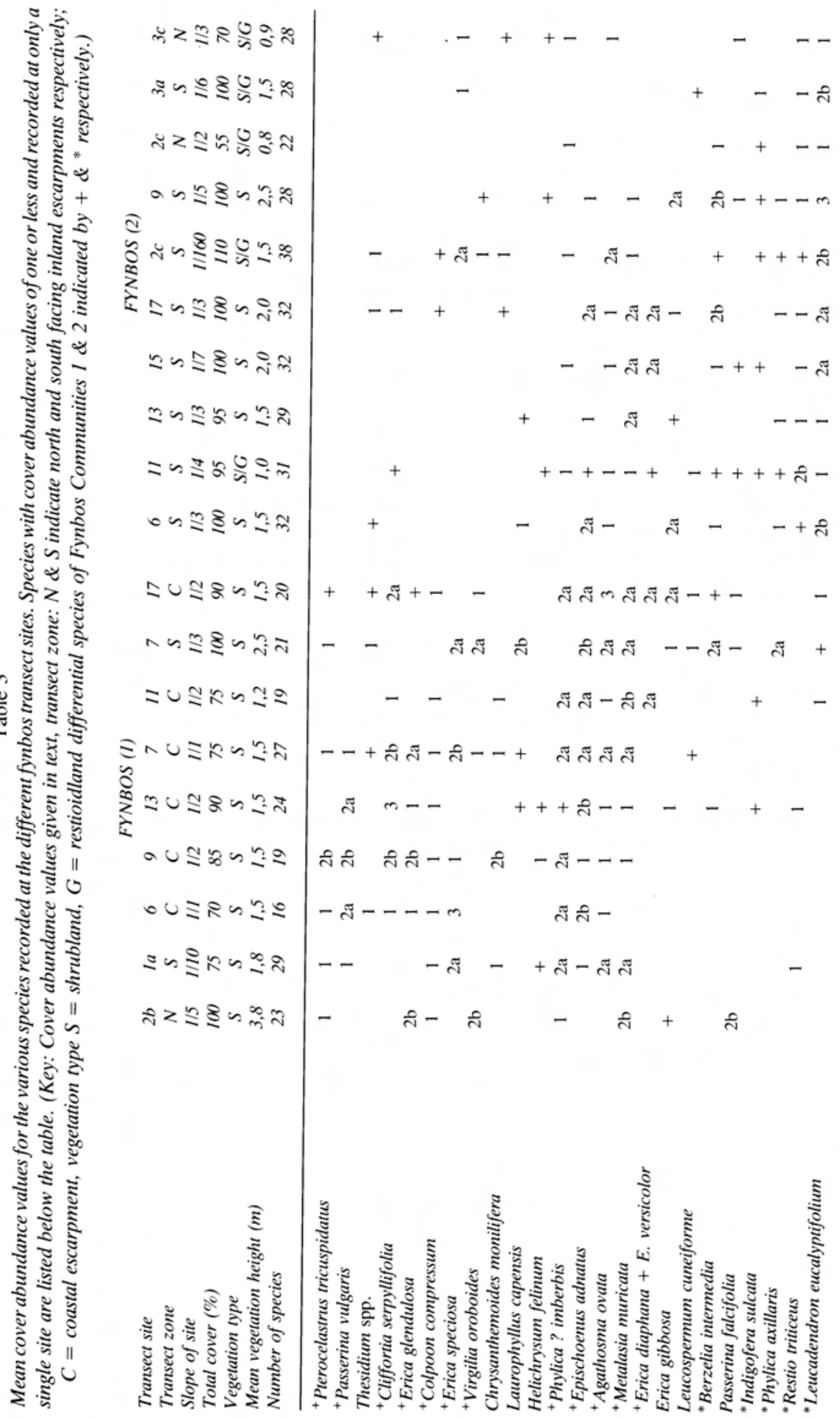




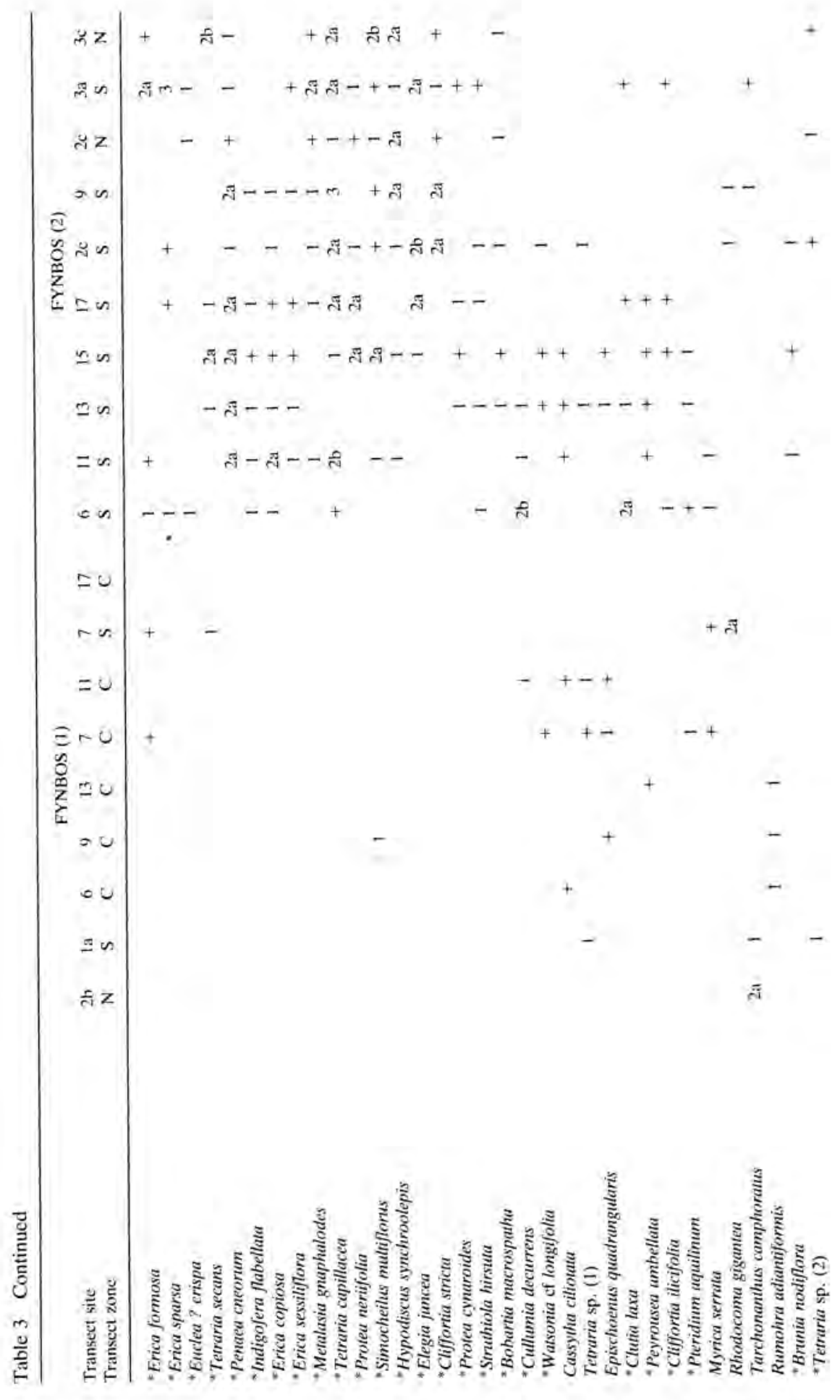




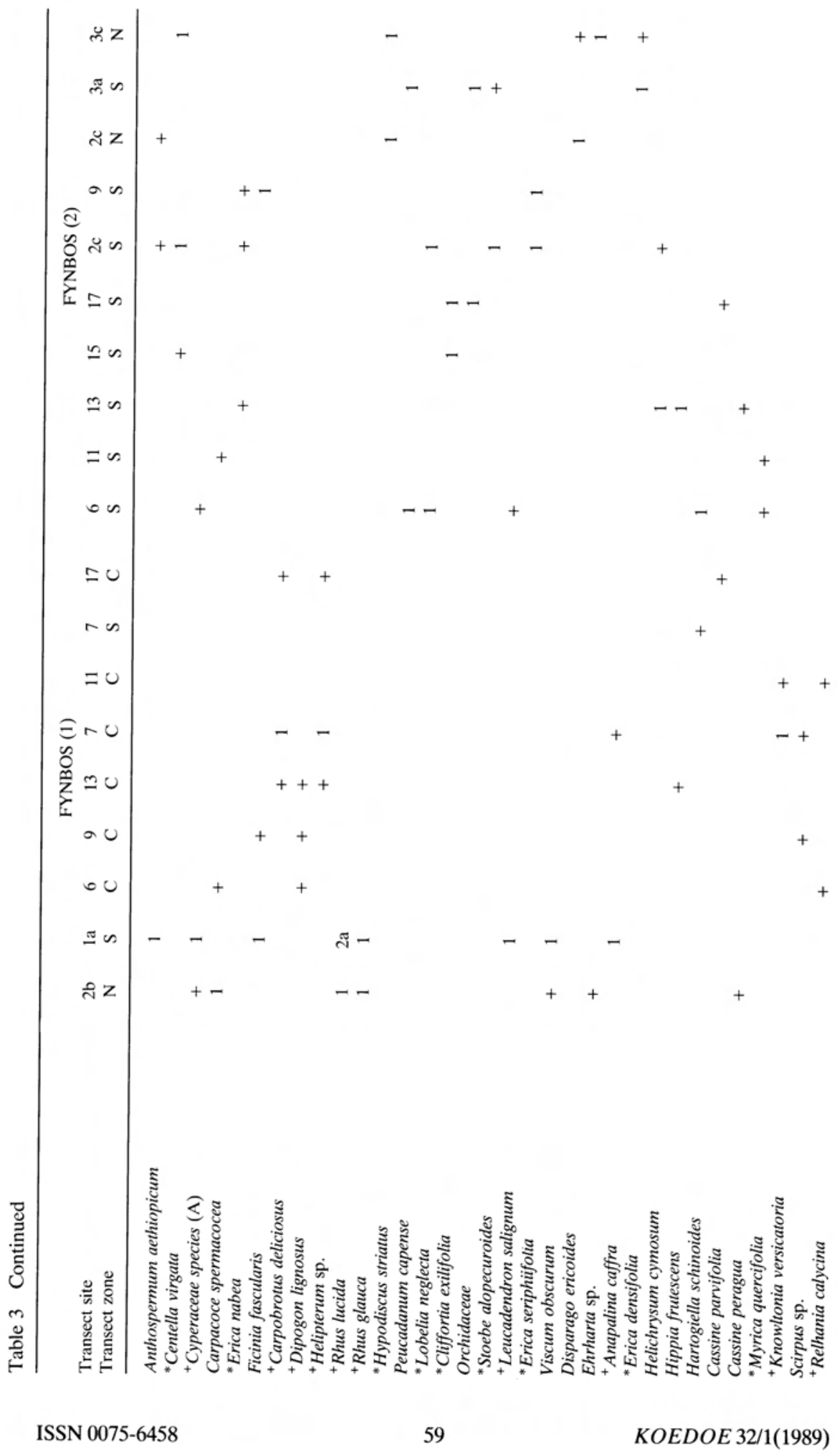




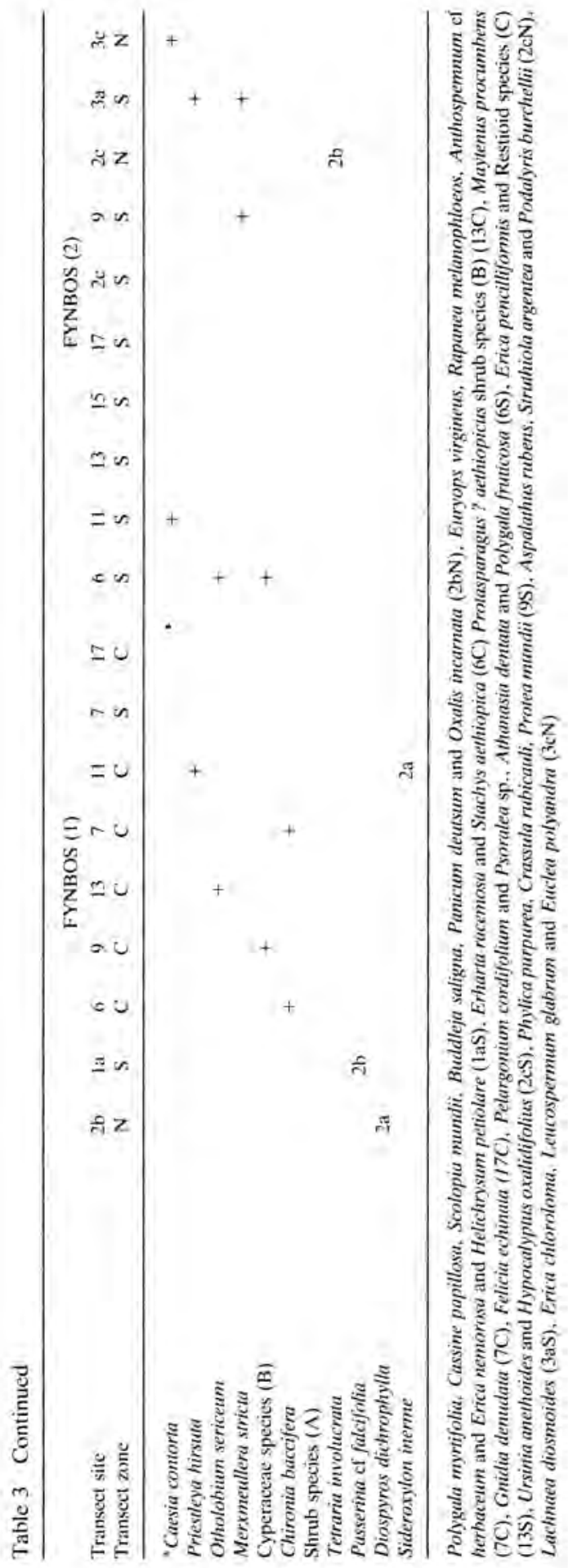


The sites on the littoral plateau formed a distinct cluster in the correspondence analysis (Fig. 4) and TWINSPAN listed 26 differential and one (Carpobrotus deliciosus) indicator species for this low $(<1,0 \mathrm{~m})$ closed (plant crowns touching) herbland community (Table 2, Fig. 6c). It covers only about 15 ha of the park.

The clustering (or similarity) of the sites from the fynbos regions was less distinct than in the other vegetation types (Fig. 4) and two communities were defined.

The first community included all sites from the steep coastal escarpment and Sites $1 \mathrm{aS}, 7 \mathrm{~S}$ and $2 \mathrm{bN}$ from the south and north facing inland escarpments (Fig. 4). TWINSPAN listed 22 differential species, but no indicator species for this community (Table 3), which consists of tall $(>2 \mathrm{~m})$ to mid-high $(1 \mathrm{~m}-2 \mathrm{~m})$, closed to mid-dense (plant crown overlapping to touching) shrublands (Fig. 6b). This community covers about 348 ha or 9 percent of the park (Fig. 2). It is less diverse than the second fynbos community studied (Table 3) and includes the Leucadendron salignum Erica spp. - Metalasia muricata and the Passerina falcifolia Communities of Pretorius et al. (1980). Although proteoid elements are uncommon in this community, it is classed as Mesic Mountain Fynbos (Moll, Campbell, Cowling, Bossi, Jarman \& Boucher 1984), because of its closed to mid-dense canopy cover and its ericoid and restioid (sedges included) components (Table 3).

\section{5 a}

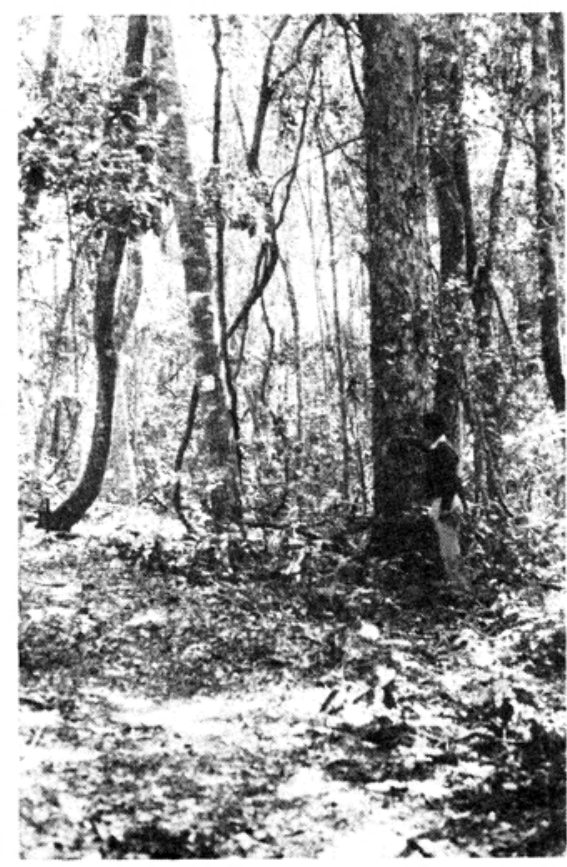

$5 b$

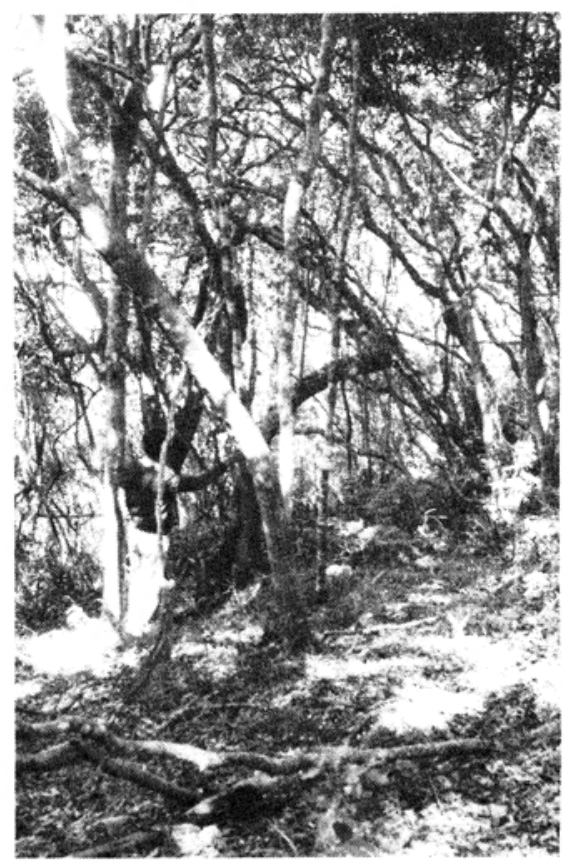

Fig. 5a and 5b. Tall (a) and stunted (b) forests of the Tsitsikamma Coastal National Park. 
6 a
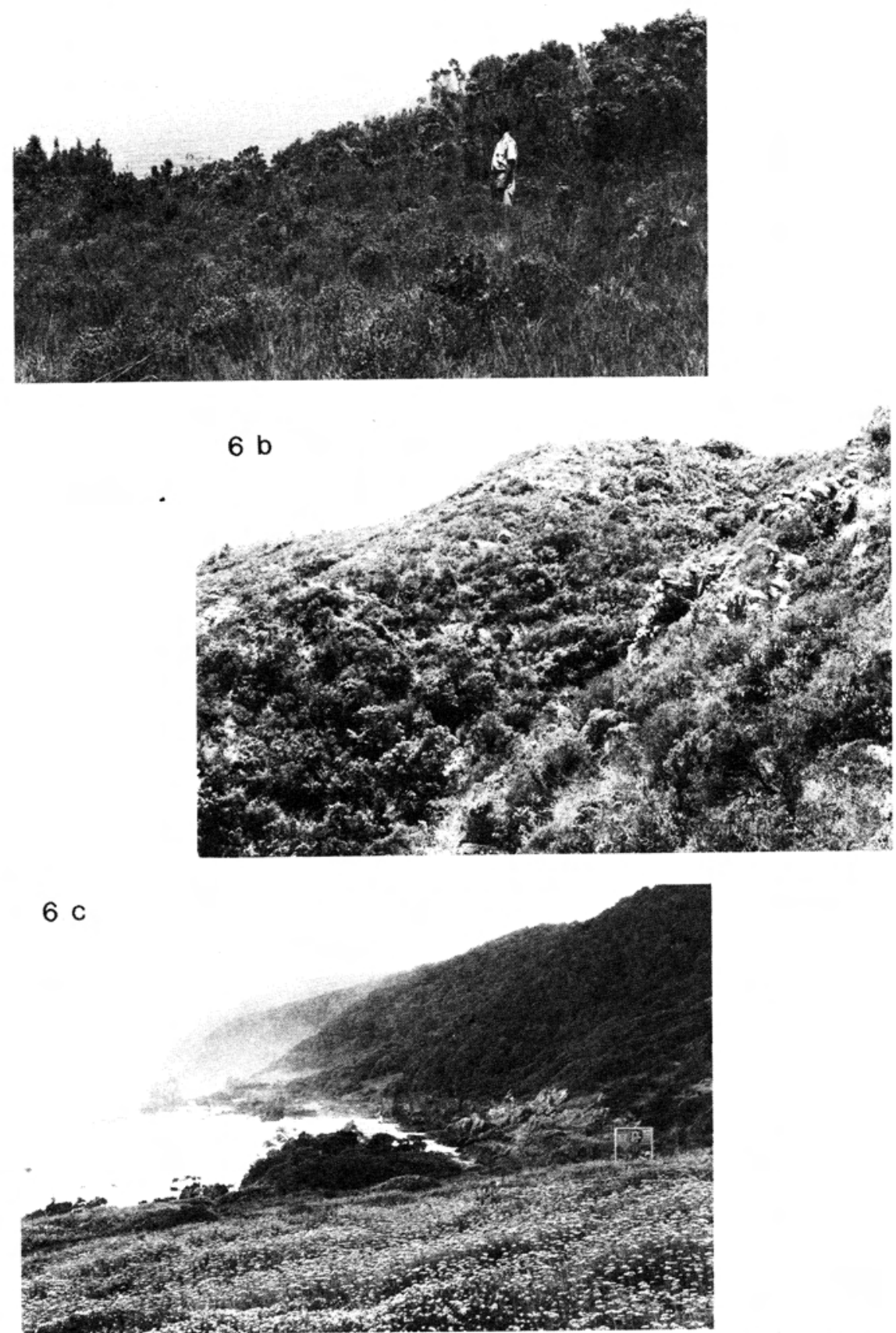

Fig. 6(a-c). Penaea cneorum - Tetraria capillacea Mesic Mountain Fynbos (6a) and the Mesic Mountain Fynbos found primarily on the coastal escarpment of the Tsitsikamma Coastal National Park (6b), as well as the herblands found on the littoral plateau (6c). 
The second fynbos community incorporated all the sites (except Site 1aS and $7 \mathrm{~S}$ ) from the south facing and two (Sites $2 \mathrm{cN}$ and $3 \mathrm{cN}$ ) from the north facing inland escarpments. Its structure varies from tall $(>2 \mathrm{~m})$ closed (plant crowns overlapping) shrublands to low $(<1 \mathrm{~m})$ open restioid-shrublands (Fig. 6a), with the latter usually being found in the drier areas of the escarpment. TWINSPAN listed 38 differential species, of which two (Penaea cneorum and Tetraria capillacea) are indicator species for this community (Table 3 ). Its main floristic components are proteoid, ericoid and restioid (sedges included) elements (Table 3) and it is therefore Mesic Mountain Fynbos (Moll et al. 1984). This Penaea cneorum - Tetraria capillacea community covers about 1038 ha (or 26 percent) of the park (Fig. 2) and occurs in areas underlaid by geological formations of the Table Mountain Group. It incorporates the Leucadendron eucalyptifolium, the Simocheilus multiflorus - Tetraria - Hypodiscus and the Priestleya hirsuta - L. eucalyptifolium - Simocheilus - Hypodiscus - Tetraria Communities of Pretorius et al. (1980).

\section{Discussion}

The forest community delineated by TWINSPAN in this study encompasses the Very Dry Scrub Forest and Dry High Forest groups of Von Breitenbach (1974). Its floristic composition included over 70 percent of the Afromontane tree species of the Knysna enclave (White 1978), as well as many of the plant species found in the Kromme River- and KnysnaKaffrarian Thickets of the Humansdorp area (Cowling 1984). The community is regarded as Afromontane Forest and as part of the large Knysna Afromontane Forest complex, which forms a belt of isolated forest patches along the coastal plateau and lower slopes of the Outeniqua and Tsitsikamma Mountains (Von Breitenbach 1974; White 1978).

These Afromontane Forests are restricted to sites where soil moisture is available throughout the year and compared to allied forests of Transkei, Natal and Transvaal they have a low species diversity (White 1978; Cowling 1984; Table 1). The patches of forests in the park are often bordered by fynbos and the boundaries between the two communities are usually fairly abrupt. This is apparently due to the effect of fires buming to the forest edges. In the Royal Natal National Park biennial burns of the neighbouring grasslands appear to be detrimentally affecting some of the Podocarpus latifolius forest patches, which are contracting in size (Everard 1986). Geldenhuys (1987) found that the distribution of the major Afromontane Forest patches in the Tsitsikamma Region appears to be determined by recurrent, but sporadic and severe berg-wind fires. Noting the reductions of forest areas in southern Africa over the last century, Moll (1972) stated that unless our forests are scientifically managed, the drier vegetation types (e.g. fynbos) will continue to replace them. He proposed a form of active management (e.g. planting trees and constructing effective fire breaks) to preserve the Mistbelt Mixed Podocarpus Forests of Natal and possibly this approach should be adopted in the park. 
The Carpobrotus deliciosus Herbland sampled on the littoral plateau of the park includes only about 23 percent of the diagnostic species of the South Coast Dune Fynbos communities recorded by Cowling (1984) in the Humansdorp coastal region. It also differs markedly from the Dune Shrublands of the Robberg Nature Reserve (Metalasia - Restio Microphyllous Evergreen Dune Shrubland, (Taylor 1970a)) and the Goukamma Nature Reserve (Helichrysum teretifolium - Metalasia muricata Dune Fynbos, (Van der Merwe 1976)) and is probably peculiar to the moist Tsitsikamma littoral plateau.

The Penaea cneorum - Tetraria capillacea Fynbos Community of the park shows a greater similarity to the (Mesic) South East Mountain Fynbos of the Elandsberg Mountains than to the Grassy Fynbos of the neighbouring Humansdorp forelands (Fig. 1), and its floristic component (Table 3) includes about 75 percent of the diagnostic species of this Mountain Fynbos group, as opposed to 25 percent in the latter instance (Table 3; Cowling 1984). Cowling (1984) found that soil moisture often plays a critical role in the distribution of phytocoena. The soils of many of the above Grassy Fynbos and Mountain Fynbos regions are similar (namely sandy, and infertile soils, derived from quartzites and sandstone of the Table Mountain Group (Toerien 1976; Cowling 1984; Fig. 2)). The annual rainfall and air temperatures of the Mountain Fynbos areas are respectively, however, higher (ca $900 \mathrm{~mm}-1140 \mathrm{~mm} \mathrm{cf} 400 \mathrm{~mm}-750 \mathrm{~mm})$ and lower $\left(\right.$ ca $15,0^{\circ} \mathrm{C}$ cf $17,0^{\circ} \mathrm{C}$ ) than in the Grassy Fynbos regions (Fig. 2; Cowling 1984) and therefore provide a moisture environment. The Penaea cneorum - Tetraria capillacea Community of the park also appears to be fairly similar to the Mixed Sclerophyllous Scrub of Kruger (1979) and to a lesser extent to the Otterford Wet Proteoid Fynbos of Campbell (1985), which are found on the mountains of the "southern" Cape.

The clearing of the indigenous vegetation in the Tsitsikamma region for the development of pine plantations and agricultural pastures has separated the (mesic) fynbos communities of the park from the Wet Mountain Fynbos of the neighbouring Tsitsikamma Mountains (Moll et al. 1984). This and the uncontrolled spread of prescribed and accidental burns from neighbouring regions has affected the natural fire regime of the park, which could influence the long-term composition of the fynbos community (Moll, McKenzie \& McLachlan 1980; Bond 1980; Cowling 1984; Van Wilgen \& Viviers 1985). At present these fynbos communities are burnt very irregularly, whereas an $8-12$ year burning cycle is recommended by Pretorius et al. (1980) and the fires should be in late summer or early autumn (Bond, Vlok \& Viviers 1984; Van Wilgen \& Viviers 1985).

The shrubland fynbos community recorded primarily on the exposed coastal escarpment of the park has no diagnostic species (Table 3). Floristically it differs from the more mesic Penaea cneorum - Tetraria capillacea Fynbos of the inland escarpments of the park (Fig. 4; Table 3) and from the South East Mountain Fynbos and Grassy Fynbos found in the neighbouring Humansdorp region (Cowling 1984). It is, however, fairly similar (sharing about 65 percent of the species) to the Erica - Phylica Microphyllous Evergreen Steppe Fynbos recorded by Taylor (1970a) in the Robberg Nature Reserve (Fig. 1) 
Much of the Afromontane Forest and Mountain Fynbos areas in the southern Cape are controlled by the Departments of Environment Affairs and Nature and Environmental Conservation of the Cape Provincial Administration, whose policies provide for preservation in these areas (Von Breitenbach 1974; Kruger 1977 in Cowling 1984). Although some of this land could be afforested in the future, theoretically the conservation situation appears good (Cowling 1984) and no special priority needs therefore to be placed on the vegetation of the park.

\section{Acknowledgements}

We are indebted to Dr H. Taylor (Botanical Research Institute) for his encouragement and constructive criticism of the manuscript, Dr B. Talbot (University of Port Elizabeth) for his help with the analysis of the data and Mr J. Vlok (Saasveld Forestry Research Centre), Mrs F. Hanekom, Mrs Snyman and Dr J. Rourkes (Kirstenbosch Botanical Gardens) for the identification of certain plant specimens. Thanks are also extended to Messrs. D. Willemse, D. Reynell, A. West (Department of Environment Affairs, Forestry) and Mrs C. Smit and E. du Bruyn for their assistance in this project, which was made possible through the financial support given by the National Parks Board.

\section{References}

BOND, W.J. 1980. Fire and senescent fynbos in the Swartberg, southern Cape. S. Afr. For. J. 114: $68-71$

BOND W.J. 1981. Vegetation gradients in the southern Cape mountains. M.Sc. thesis, University of Cape Town.

BOND W.J., J. VLOK and M. VIVIERS. 1984. Variations in seedling recruitment in fire adapted Cape Proteaceae and its causes. J. Ecol. 72: 209-221.

BOND, F.B. and P. GOLDBLATT. 1984. Plants of the Cape flora. A descriptive catalogue. J.S. Afr. Bot. Suppl. vol. no 13.

CAMPBELL, B.M. 1985. A classification of the mountain vegetation of the Fynbos Biome. Mem. bot. Surv. S. Afr. 50: 1-20.

CAMPBELL, B.M., R.M. COWLING, W.J. BOND, and F.J. KRUGER. 1981. Structural characterisation of vegetation in the Fynbos Biome. S. Afr. Nat. Sci. Prog. Report No. 53. Pretoria: CSIR.

COWLING, R.M. 1984. Syntaxonomic and synecological study in the Humansdorp region of Fynbos Biome. Bothalia 15 (1 \& 2): 175-227.

COURTNEY-LATIMER, M., G.G. SMITH, H. BOKELMANN and A. BATTEN. 1967. The flowering plants of the Tsitsikamma Forest and Coastal National Park. Pretoria: National Parks Board.

EVERARD, D.A. 1986. The effect of fire on the Podocarpus latifolius forests of the Royal National Park, Natal Drakensberg: S. Afr. J. Bot. 52: 60-66.

GOVERNMENT GAZETTE, 21 June 1974, Notice No. 1053. Pretoria: Government Printers.

GELDENHUYS, C.J. 1987. Bergwind fires determine forest distribution in the southern Cape. Poster paper in National Conference on Long-term Data Series Relating to Southern Africa's Renewable Natural Resources. Pretoria: CSIR.

GELDENHUYS, C.J., R.S. KNIGHT and M.L. JARMAN. 1987. Proforma for structural classification of southern African indigenous forests. A report of the Terrestrial Ecosystem Sections, Ecosystem Programmes, Occasional Report No. 21: Pretoria: CSIR.

GROBLER, P.J. and J. MARAIS. 1967. Die plantegroei van die Nasionale Bontebokpark, Swellendam. Koedoe 10: 132-148. 
HANEKOM, N. and D. BOWER. 1988. A summary of abiotic factors and research work done in the Tsitsikamma National Park. Internal Report: National Parks Board. Unpubl.

HILL, M.O. 1973. Reciprocal averaging: an eigenvector of ordination. J. Ecol. 61: 237-249.

HILL, M.O. 1979. TWINSPAN - a FORTRAN program for averaging multivariate data in an ordered two way table by classification of individuals and attributes. Section of Ecology and Systematics, Cornell University, Ithaca, New York.

KRUGER, F.J. 1977. Ecological reserves in the Cape Fynbos: towards a strategy for conservation. S. Afr. J. Sci 73: 81-85.

KRUGER, F.J. 1979. South African heathlands. In: SPECHT, R.L. (ed.). Ecosystems of the World, Vol 9 A, Heathlands and Related Shrublands. Descriptive Studies. Amsterdam: Elsevier.

McKENZIE, B. 1978. A quantitative and qualitative study of the indigenous forests of the south-western Cape. M.Sc. thesis, University of Cape Town.

MOLL, E.J. 1972. The current status of mistbelt mixed Podocarpus forest in Natal. Bothalia 10: $595-598$

MOLL, E.J., B.M. CAMPBELL, R.M. COWLING, L. BOSSI, M.L. JARMAN and C. BOUCHER. 1984. A description of the major vegetation categories in and adjacent to the fynbos biome. S. Afr. Nat. Sci. Prog. Report No. 83. Pretoria: CSIR.

MOLL, E.J., B. McKENZIE and D. McLACHLAN. 1980. A possible explanation for the lack of trees in the fynbos, Cape Province, South Africa Biol. Cons. 17: 221-228.

PENZHORN, B.L. and M.C. OLIVIER. 1974. A systematic check list of flowering plants of the Addo Elephant National Park. Koedoe 17: 121-136.

PRETORIUS, "G., W. BOND, P. ODENDAAL, C. GELDENHUYS and J.J. BREYTENBACH. 1980. De Vasselot Natuurreservaat Bestuurplan 1979/80 - 1983/84. Internal Report. Department of Forestry, RSA.

RYCROFT, H.B. 1980. Trees of Tsitsikamma National Parks. Pretoria: National Parks Board (RSA).

STATUTES OF THE REPUBLIC OF SOUTH AFRICA 1976. National Parks Act, 1976 (Act 57 of 1976). Pretoria: Government Printers.

TAYLOR, H.C. 1969. A vegetation survey of the Cape of Good Hope Nature Reserve. M. Sc. thesis, University of Cape Town.

TAYLOR, H.C. 1970a. I.B.P. checksheet for the Robberg Nature Reserve. Stellenbosch: Botanical Research Institute.

TAYLOR, H.C. 1970b. I.B.P. checksheet for the Riversdale Nature Reserve. Stellenbosch: Botanical Research Institute.

TER BRAAK, C.J.S. 1987. "CANOCO - a FORTRAN program for canonical community ordination by partially detrended canonical correspondence analysis, principal component analysis and redundancy analysis (Version 2.0)" T.N.O. Institute of Applied Computer Science, Wageningen, Netherland.

TOERIEN, D.K. 1976. Geologie van die Tsitsikamma kusstrook. Koedoe 9: 31-42.

VAN DER MERWE, C.V. 1976. Die plantekologiese aspekte en bestuursprobleme van die Goukamma-Natuurreservaat. M.Sc. thesis, University of Stellenbosch.

VAN DER MERWE, C.V. 1977. 'n Plantegroeiopname van die De Hoop Natuurreservaat. Bontebok 1: 1-29.

VAN WILGEN, B.W. and M. VIVIERS. 1985. The effect of season of fire on serotinous Proteaceae in the Western Cape and implications for fynbos management. S. Afr. For. J. 49-53.

VON BREITENBACH, F. 1974. Southern Cape Forest and Trees. Pretoria: Government Printers.

WERGER, M.J.A. 1974. On concepts and techniques applied in the Zurich-Montpellier method of vegetation survey. Bothalia 11: 309-323.

WHITE. F. 1978. The Afromontane Region. Pp. 463-513. In: WERGER, M.J.A. (ed.). Biogeography and Ecology of Southern Africa. The Hague: Junk. 